\title{
Re-Invent the Wheel! Reimagining teacher/student roles in content-based language learning environments
}

\author{
David Swartz, Universidade Nova de Lisboa
}

Recepción: 07/07/2018 | Aceptado: 30/04/2019

Correspondencia a través de ORCID: David Swartz

iD 0000-0001-7952-4795

Citar: Swartz, D (2019). Re-Invent the Wheel! Reimagining teacher/student roles in content-based language learning environments. ReiDoCrea - Monográfico sobre Perspectivas transnacionales en la enseñanza de lenguas, 8(3), 214-224.

\begin{abstract}
What if instead of providing predetermined content for language courses, and instead of framing the questions and discourse we ask students to respond to, students themselves were required to bring in their own content, initiate and respond to their own questions, and ultimately, to assess and evaluate their own work? My paper outlines an alternative approach to content-based language learning wherein students are made responsible for sharing, editing and evaluating each other's work, as well as for providing the contents of the course's curriculum itself. It is time to truly democratize education, to re-evaluate the teacher's role in the classroom from the standpoint of assumed ignorance rather than presumed knowledge, and finally, to prepare for a classroom in which every student benefit from the presence and involvement of every other student. In this essay, I offer us a chance to look closer into this subject: first, to become conscious of the shortcomings of the traditional content-based language learning scenario, and secondly, to bring radical change to the classroom: to re-invent the wheel!
\end{abstract}

Keywords: Collaborative evaluation

\section{¡Reinventar La Rueda!}

Reimaginar los papeles del docente y de los estudiantes en la enseñanza del lenguaje en cursos basados en contenido predeterminado.

Resumen: ¿Que pasaría si en vez de proveer contenido predeterminado para cursos de lenguaje en niveles de secundaria y nivel universitario, y en vez de proponer preguntas y discursos, le preguntamos a los estudiantes que traigan su propio contenido, que inicien y respondan a sus propias preguntas, y finalmente, que valoren y evalúen su propio trabajo? Mi ensayo delinea una alternativa al aprendizaje del lenguaje basado en contenido predeterminado, una visión en la cual los estudiantes no solo comparten su trabajo con sus compañeros, sino que son responsables de compartir, editar y evaluar, como también de proveer el contenido del curso. Es hora de democratizar educación realmente, de reevaluar el papel del maestro en la clase desde el punto de vista de ignorancia supuesta en vez de conocimiento asumido, y por ultimo, de prepararse para una clase en la cual cada estudiante se beneficie por la presencia y participación de cada otro estudiante. En este ensayo, propongo una oportunidad de explorar este tema más de cerca: primero, para concientizarnos de las falencias del escenario tradicional de la enseñanza del lenguaje basado en contenido predeterminado, y segundo, para traer un cambio radical al salón de clase: ipara reinventar la rueda!

Palabras Clave: Evaluación colaborativa

\section{Introduction}

Why would anyone in their right mind want to re-invent the wheel? It sounds like an absurd thing to do. A lot of people will tell you not to waste your time. During my stay in Granada in the late spring of 2018, I came across some verses by Federico García Lorca 
(1898-1936) which mention such a wheel, casting light on its importance as a symbol. Lorca wrote:

Porque si la rueda olvida su fórmula ya puede cantar desnuda con las mandas de caballos, y si una llama quema los helados proyectos

el cielo tendrá que huir ante el tumulto de las ventanas

Because if the wheel forgets its formula, It will sing naked with herds of horses;

And if a flame burns the frozen blueprints, The sky will have to flee before the tumult of windows.

(Lorca, 2002, p. 44)

If one doesn't constantly re-invent the wheel, it will forget its purpose and become unconscious. In Lorca's words: "it will forget its formula." I don't know if that is a good or bad thing for a poet. For a student or teacher on the other hand, it could be confusing when "the sky ... flees before the tumult of windows", especially if one considers oneself as a kind of window, or if windows represent different points of view that one can look through. And when blueprints are burned and normalized ways of looking at things shift, "the sky will have to flee before the tumult of windows", for the authority of the sky will amount to nothing in the face of the myriad viewpoints of man's imagination, and the wheel will be released from its traditional purpose and re-invented for another.

Shakespeare radically revolutionized love poetry by addressing his future reader as his muse; in effect, he created works of literature that allow the reader to become the writer's "better part". In respect to the teaching field, and to foreign language teaching specifically, this is the direction I am heading in - that is, towards finding a way to allow students to take over the learning stage by asking their own questions, providing their own content, developing their own assessment criteria, and ultimately, evaluating their own and each other's projects. My hope is that this method will help students and teachers integrate the love of themselves and the love of the other as one and the same project. Shakespeare did this by addressing his Sonnets to his future readers as if they themselves had provided them with life. Let's see if a similar thing can be done by addressing one's language course to one's students as if they themselves were responsible for inventing it.

The American poet Walt Whitman wrote the following lines in his poem "A Song of the Rolling Earth" back in 1856:

No one can acquire for another - not one,

Not one can grow for another - not one.

The song is to the singer, and comes back most to him,

The teaching is to the teacher, and comes back most to him,

...

And no man understands any greatness or goodness but his own, or the indication of his own.

(Whitman, p.178-179) 
The teaching and learning scenario is inherently structured in such a way that content returns to the teacher. The reward of teaching is learning. The giver gets back what he gives. Not only that, but the teacher, at least according to Whitman, cannot acquire knowledge for his or her students. As a consequence, as teachers, if we truly care about our students' acquisition of knowledge and their confidence to implement it, we need to find a way to turn them into teachers (that is, in order to make sure that the efforts they put in come back to them).

The first thing the teacher does is to ask questions. He uses the question to elicit verbal and written responses. Meanwhile, by asking questions, ostensibly opening up a space for exploration, the teacher puts his own interests into action. Or, if a teacher's questions have been predetermined by committee or in consultation with other teachers, those questions pertain to shared teacher interests or institutional interests. While part of such interests involves the intent to teach students to express themselves effectively in a new language, the decision to ask particular questions rather than others, cannot be explained in the same way. The same thing can be said about the content introduced to teach language courses. In both cases, the content and questions utilized to direct class discussions and to initiate assessment responses, relate back to teachers' rather than students' interests.

Whitman's idea that "no man understands any greatness or goodness but his own, or the indication of his own", strikes me as an important insight into the teacherstudent dynamic. It suggests that in order to recognize the positive value of content, students need to envision their appropriation of such content as providing evidence of their own goodness or greatness. Students can own this knowledge by translating it into discourse, but they need to appropriate it in a personal way to do so; that is, it needs to be in line with their interests, goals and ideals of self-affirmation.

\section{Objectives}

My essay is an attempt to reimagine a learning environment in which students are able to get the most out of their experience, by radically expanding the possibilities of the traditional learning experience.

Content based language teaching is a good place to begin this discussion because of its openness to new approaches to learning. My premise is that the content base or subject matter attended to in such classes is never a target language or specific content, but rather, the individual student attending our class.

Ultimately, the aspect of teaching that I am most concerned with is the assumption of ignorance versus the presumption of knowledge on the part of the teacher. The world has known plenty of advocates for both approaches to teaching, and even those who come across as advocates of the former are certainly bringing their own range of presuppositions to the table in the form of the questions they ask their students during class and present as subjects to be addressed in their assessments. Each teaching method has its own set of criteria but they all hinge upon the way individual teacher's frame their questions. The intention behind the Socratic type of questioning method was to elicit true-knowledge by making one aware of one's ignorance. But in the classroom, this is clearly not the goal. Rather than make our students feel ignorant, we would like to make them feel connected to relevant and accessible content. Teacher's questions are meant to prompt imaginative relevant responses. The trouble is, as long as teachers are asking the questions and not the students, there is no reason to believe that students responses will be based on anything other than their interest in passing their courses, and hence, pleasing their parents and teachers. 
While the goal of a content-based language class is ostensibly for students to become more fluent in a target language, the question is, since content is also a key component of the learning process, how will the introduction of this or that content improve or lessen the effectiveness of the course? There is plenty of evidence to confirm that relevant theme-based topics will help students learn the target language. But what is to support the choice of material in such cases? And is such content merely incidental to the learning process?

It is easy to find analogies to what I am suggesting in other fields: for example, in the visual arts and literature, the subject-matter is no longer about who is providing the content, what is being represented, or even how it is being represented, but rather, by who is experiencing the representation. In the end, the subject of the novel or painting or poem or film is none other than the spectator or reader. In the field of education, where we have always imagined the subject to be the knowledge or skill that we are teaching, or the teacher's own genius, it is time to take a closer look into the presuppositions that go into making such assumptions.

\section{Method}

My suggested program is meant to allow students to participate more effectively and meaningfully in the target language not only by actively creating content and responding to their peer's content, but by advancing their practice of writing, editing and critical thinking. Having students make mandatory aesthetic judgments, grammar judgements, style judgements, content judgments, teachers will help students transform themselves into active learners. Moreover, there will be more fairness and objectivity with respect to assessments, more feedback for students on an ongoing basis, more student-to-student contact and respect, more original and diverse content, and a highlighted connection drawn between one's own work and the work of others.

In this model, peer assessment would be the main evaluative system used throughout the course; minimizing teacher grading but not the teacher's role in facilitating and moderating the grading. What I am proposing will take more time and effort on the part of everyone but lead to a new kind of enriched learning experience. The teacher's role in this approach to language learning would be to facilitate student presentations, explore available resources, initiate collaborative exercises, introduce grammatical usages and vocabulary, help students understand how to ask their own questions, discuss assessment criteria, and finally, to moderate their students' critical evaluations of their own and each other's projects.

In practice, for each assessment, each student would be given the task of coming up with a question or set of questions that they would want to explore in a presentation or essay or creative writing piece, understanding that they will be both evaluated by their peers on the originality of the question they ask as well as in the way they follow it up in their work. Moreover, they are to know that they too will have a say in their final assessment by having written out their own assessment criteria and by contributing to their own assessment score, to the same extent as their peers. Each student will write out his or her own set of criteria to be used by their peers to evaluate their own papers and presentations. The student will in turn receive comments and grading from each student in the class as well as from the teacher. All grading and commenting would be carried out as anonymously as possible. The student receives the average grade. The teacher moderates the process and evaluates student participation.

The teacher is the leader of a group of students; she sets the pace of the class, is the class director, suggests links, resources, examples of writing, editing techniques 
and cultural content. Additionally, the teacher moderates the assessment process, assists students in drawing up their criteria, and assesses the quality of their peer assessments. Moreover, the teacher ought to participate in anonymous peer assessment and contribute feedback to their student's work and progress.

\section{Preliminary Research}

According to a seminal study on content-based language learning by Donna Brinton (1989), "the target language is the vehicle through which subject matter content is learned rather than as the immediate object of study" (Brinton et al., p. 5). But if that is the case, just what is the subject matter of study? A more neutral definition might put it like this: the subject matter of study is the student; which is to say, the student is the subject that matters. And, as a result of the subject mattering, the importance of the choice and use of content in the classroom becomes paramount.

Academic studies of content-based language instruction are full of contradictions, since the context for any particular learning environment is radically unique. According to Genesee (1994) content "...need not be academic but can include any topic, theme, or non-language issue of interest or importance to the learners" (p. 3). The idea here stated by Genesee supports the importance of student's interests in the determining of subject-content. Closer to home, Mimi Met (1991) proposes that "... 'content' in contentbased language programs, represents material that is cognitively engaging and demanding for the learner, and is material that extends beyond the target language or target culture" (p. 150). Still, if students are, in fact, the veritable subject of their studies (above and beyond what they are learning), what about the material content to be discussed? Where should it come from?

One thing is for sure, students learn languages best when there is an emphasis on relevant, meaningful content, rather than on the language itself: people learn languages by using them. According to Lightbown \& Spada, content-based language learning is enhanced through "the negotiation of meaning, form and content" (Lightbown \& Spada, 1993). This last statement is a clear indicator that the groundwork has already been set for this discussion.

\section{Discussion}

Let's return for a moment to the title of this paper: "Re-Invent the Wheel!". In response, one might ask: 'why should we re-invent something if it already works?' I have deliberately stated my title with an exclamation mark to emphasizes the necessity of taking this leap of faith. Nevertheless, there is a wheel already in motion. It's the kind of wheel that gets people from place to place. It serves a practical function. That the teacher's role is to impart knowledge and assess student's abilities, is the way it rolls along in traditional educational environments.

While Marcel Duchamp famously re-invented the wheel as a readymade work of art back in 1915, if we look closely at his example, we might come to the conclusion that Duchamp's readymade wheel is as outdated as all the other ideas about wheels that came before it, since it is precisely this kind of readymade course of study that students might find irrelevant in today's classroom. It is, after all, somebody else's wheel. The readymade wheel belongs neither to the teacher, the student, nor the artist. The teacher merely inherited the wheel, or perhaps he chose it out after many years of careful study. But still, it belongs to the past. It's of no interest to today's students. Today's wheel is the student's wheel. It's about students becoming their own wheel: their own subject matter. 
An educational revolution occurs not when teachers become students and students teachers, but when both realize that this transformation has already happened and decide to do something about it.

While teachers' horizons are being broadened by the courageous efforts of their students' original research (carried out in response to their own interest-laden questions), students themselves, having pinned their hopes for a good reception on the biased judgements of their individual teachers, are apt to disregard the original content being produced by their own classmates.

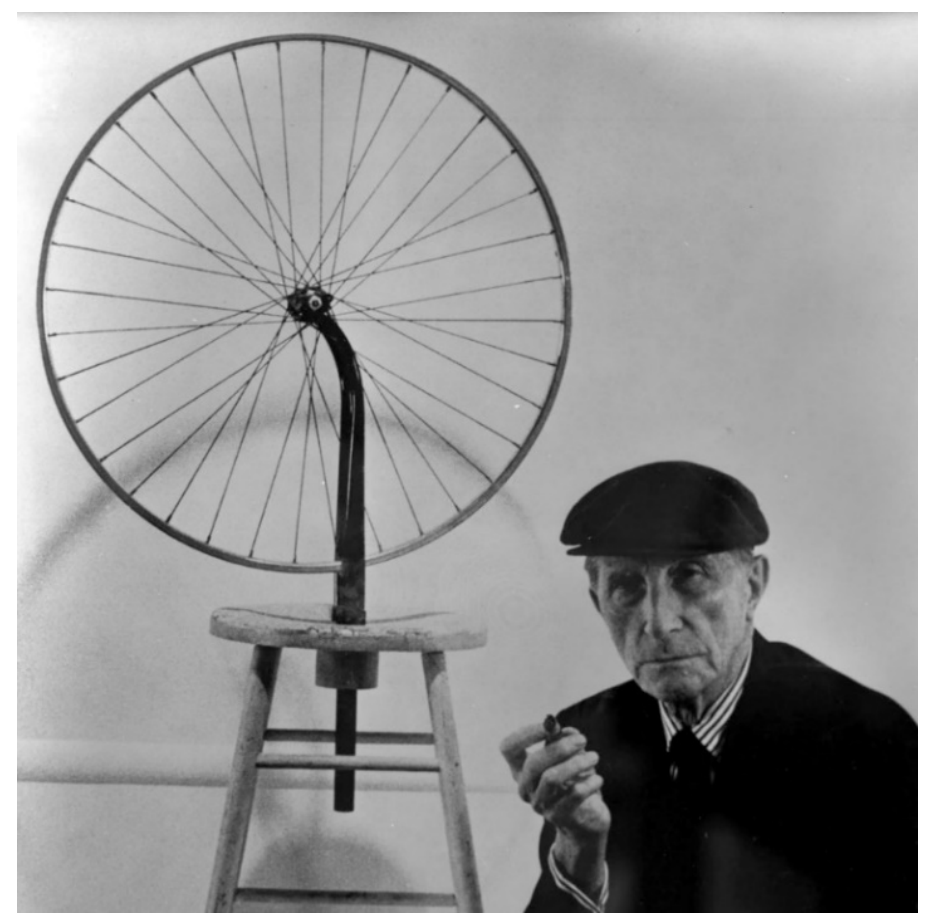

Fig.1. Bicycle Wheel, Marcel Duchamp, 1913

I am suggesting these reforms based on my own experiences as a teacher and student. Although it hurts my ego to say this, I believe that students can be better providers of content than teachers, have more relevant and interesting topics to choose from, and that their self and peer assessments will provide fairer evaluations of their work than teachers' evaluations. More significantly, since their content and questions will be self-generated, leading to increased personal and academic self-confidence and autonomy, students will learn with more eagerness and accelerate their learning. The final grade would be based on a combination of grades received by the students through peer assessment, participation in content sharing and creation, and the teacher's evaluation of the comments provided by individual students as feedback to other students. In the end, teachers would assess their student's assessments.

A different learning environment than we are used to is possible. It may be as difficult for students to change as it is for teachers.

My method attempts to strategically employ the assumption of ignorance, without intimidating students through rhetorical questioning. This assumption of ignorance is critical to the success of the classroom. 
Just as Marcel Duchamp's' wheel transformed a functioning bicycle wheel into an art object, our new wheel is going to have an entirely new function than the old one; our new wheel is going to make the utilitarian wheel, the Socratic wheel and the found object-subject wheel obsolete: in their place, we're going to reimagine the wheel as an individual living-breathing student.

The kinds of cultural critiques that became prevalent in the 1960s, including Marshall McLuhan's and Noam Chomsky's critiques of mass media, Foucault's deconstruction of institutionalized power structures, Edward Said's critique of western imperialism, feminist and Marxist critiques of different forms of discourse, may be thought of as turning points in the way we look at the conditions and structures of knowledge and power. We have become increasingly aware of the fact that the motivations behind the framing of knowledge and discourse, including the way all forms of media manipulate our ways of thinking, can be traced back to private and institutional interests. The most important thing we can take away from such cultural critiques when it comes to assessing our content-based language learning curriculums and methodologies, is how the questions we ask our students form the answers available to them. And if we've convinced ourselves that we are primarily teaching language acquisition and not ideas or content, the questions I am alluding to are even more relevant. Most importantly then, we ought to become aware that there is nothing random or unconscious about the

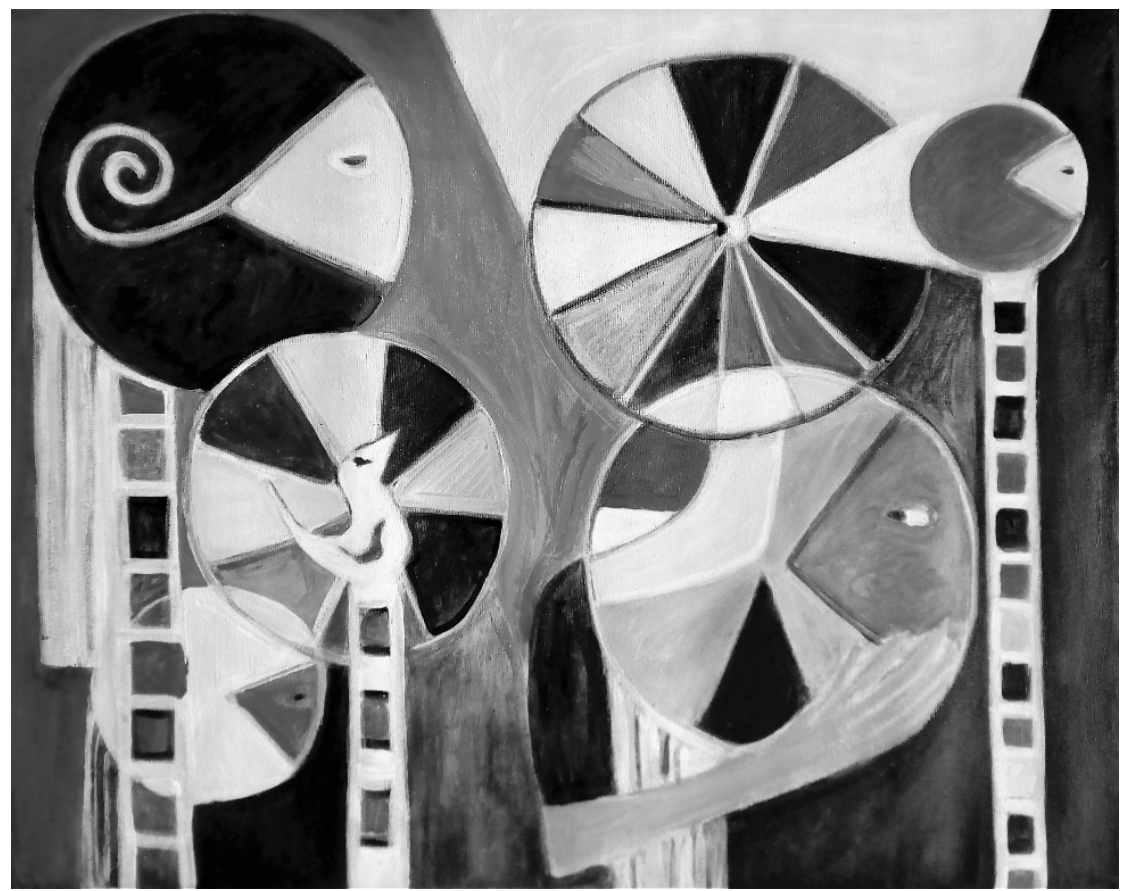

Fig.2. Re-Invent The Wheel!, David Swartz, 2018

questions that we ask students to respond to. For this reason, it is important for students and educators to know what is going on when we ask questions, and for teachers to help students initiate their own. After all, no one is going to answer our questions until we are able to properly pose them by ourselves.

Looking deeper into the initiative involved in asking questions, its corresponding investment of personal interests, and its connection to introducing and negotiating meaningful content and ideas, we must bear in mind that it's not because students are unable to ask questions, introduce suitable subject-matter or talk about their personal interests or points of view, that makes it so difficult to elicit such participation, but rather, because teachers expect their students to be passive recipients of knowledge, and 
because students themselves expect their teachers to tell them what to do and how to do it.

Integrating student generated content on the syllabus, the teacher will play a vital role in developing an autonomous classroom. The teacher remains the referee and director of the class. This role should never become automated. It requires a conductor's intelligence, a director's passion and a psychologist's patience.

The presumption of knowledge or the assumption of ignorance is not something normally talked about in reference to language learning environments. Yet in the act of questioning, whether it be rhetorical questioning, or some other kind of questioning, there is always a presupposition of something that isn't being said, a kind of knowledge that exists outside of one's reach.

In antiquity, outside of the Socratic kind of questioning, some of the most significant and longstanding wisdom literature was built upon a model in which students would ask very important questions to a sage, who would answer them in turn. We find this method employed in The Upanishads and the Bhagavad Gita. In reality, when you go to a university classroom it is not the students who ask questions related to a theme, but the teachers. In this analogy, the sages are the one's answering their teacher's questions: the students.

We find questions used in the Bible on a different scale, highlighted by the wisdom of the question itself. The first question in Genesis is asked by the wily serpent in the Garden of Eden: "Did God really say, 'You must not eat from any tree in the garden'?" (NIV 3:1) (In other words, "Why haven't you eaten from the tree of knowledge?") Eve replies, "We may eat fruit from the trees in the garden, but God did say, 'You must not eat fruit from the tree that is in the middle of the garden, and you must not touch it, or you will die"' (INV 3:5) (Swartz, 2017, p. 40-41). Here, Eve invents the idea that God commanded her not to touch the fruit from the tree of knowledge, serving only to intensify the serpent's questioning. Significantly, the seemingly innocent original question posed by the serpent with the intention to trick and deceive Eve is responsible for the downfall of all humankind. Having lied through invention, Eve becomes entangled in her own words. The question, it would appear, immediately inspires thought, hesitation, doubt: not a necessarily positive or honest response but a response propelled by the question itself. The question (let it be contested) is loaded, a trick resulting in the fall of humankind! Symbolically, the question opens the doors of knowledge. Conversely, it initiates deception and makes one vulnerable to attack (p. 41).

While traditional relationships between students and teachers involve the asking and answering of questions, ultimately, it should be the students who both ask and answer such questions in the classroom. Unfortunately, that is not always what is happening. Rather, there remains a presumption of knowledge camouflaged as innocence in the asking of questions in the classroom by teachers. This makes it impossible for teachers to get beyond asking rhetorical questions to their students. Has anyone tried to put into question the question's presupposition of innocence? Just what is implied in a question? And to what extent does it determine its answer? How much ought we to trust the questioning method itself as a means of obtaining knowledge?

The person asking questions becomes the self-reflective subject of his or her own discourse, while the person asking somebody else's questions, is acting in accordance with somebody else's vision. Is this an ideal learning scenario? What kind of learning do we hope to see our student's engaging in? Which questions should students be responding to? Is there no limits to the pedagogical presumptions we ought to be making 
as teachers? How do we know that the questions we are asking our students to answer or pose for themselves are worthy questions, worthy of their short-term or long-term interests, or even if they are in their best interests? What gives us as teachers the authority of knowledge and taste to be the supreme anthologizers of good texts and media for student's consumption?

The questioning methods employed by language educators overlook the fact that the will to question is framed by the educator's own interests, ambitions, and desires, and therefore, that the answers or lack of answers that questions lead to, can only be said to have been determined by the questions themselves.

If the goal of education is not to instill fear or respect for authority but to inspire self-reliance, confidence and imaginative initiative, the authoritative roles still required by such environments involves a kind of negative capability on the part of the instructor.

For both Freud and Socrates ignorance was to be overcome by way of an intermediary endowed with the authority of knowledge - the teacher, or analyst. Just as Socrates would make his interlocutor aware of his false beliefs by questioning him about them, Freud's psychoanalytic method aimed at uncovering what had been repressed out of conscious view by his patient's "ego." (Swartz, p. 47-48) Significantly, during his career, Freud would make alterations in the way he questioned his patients, ultimately reducing the questioning method to a complete silence. Such a silent questioning cuts much deeper but still presupposes both ignorance and authority on the part of the psychoanalyst.

Lacan's analysis of the task of teaching continues Freud's train of thought. Lacan's problem is: "How can I turn ignorance into an act of teaching? Lacan claims that it is equally important for the instructor or analyst to be in a state of ignorance as it is for the patient of psychoanalysis. On the other hand, for both Freud and Lacan the presumption of the authority of knowledge must remain in place (at least from the point of view of the patient), since it is what allows the psychoanalytic process or the delivery of knowledge to create a new "original learning-disposition." (Swartz, p. 48).

The main thing to keep in mind is that the educator must assume his own ignorance since it is the assumption of ignorance from whence knowledge originates.

Of all the various means at our disposal to teach and learn foreign languages, including our own, it is through visual art, poetry, music and creative writing, that we can most effectively involve students in the process of contributing content to the curriculum in line with their own interests. In effect, by having students choose content to be shared with their class we are acknowledging their role as co-creators of their courses.

In my view, our role as educators is not to impart knowledge but to awaken selfdiscovery, which is to say, to awaken student's self-reflective creative capacities, including the resources at their command, and their abilities to think for themselves.

The subject matter of a content-based language is not the target language, not the ostensible subject under discussion, but the students themselves in their unfolding potential to initiate and conduct original research projects.

Just as each teacher can and must conduct his or her class in an independent way, each student ought to be encouraged to do the same. Conformity leads to stagnation. Creativity, to the best of a teacher's ability, ought to be taught. My hypothesis is that it is in all of our best interests to think creatively about language teaching, just as 
it would be if we were studying science, medicine, psychology, or translation. If teachers would only open the door, students themselves would lead the way towards creativity in the classroom.

Our classroom is the perfect place to allow this to happen. Creativity in the humanities begins with the initiative to ask our own questions. To do this we must be taught that it is not only acceptable to do this, but that it is essential.

According to Jiddu Krishnamurti, whereas the value of education consists in helping students become mature and independent, autonomous and creative, traditional methods of education teach students obedience, discipline, specialization, to look ahead to someone else's ideals, to be unoriginal, to hope for a better life in the future with a better outcome (Krishnamurti, 2010).

Krishnamurti has put his finger on the problem. His solution is to look at the task of the educator and student in a new light. First, he wants us to consider that each student ought to be considered and interacted with uniquely, according to their capacities and interests; moreover, that the student ought to be treated as an integrated whole and should not be encourage towards obedience. We can only understand others through love. According to Krishnamurti, there should be no coercion or force in education, no manipulation, no form or methodology that does not center around the individual student.

Instead of providing official content or enforcing students to answer particular questions as if they were on trial for having committed an unspecified crime, or evaluating our students according to preestablished criteria, I propose that as language teachers we ought to teach students how to evaluate themselves based on their new role as initiators of original questions and content; moreover, that we ought to encourage students to take their individual and collective presence and contributions seriously.

The analogy to art, where the spectator has become the spectacle, is ready to spill over into the teaching field This kind of creative expression is different than a classroom scenario; but how different is it? In the past, the teacher asked students questions. If students were to voice their own questions, they would be merely echoing the questions posed by their instructors. But why should students be forced to answer someone else's questions, as if they didn't know how to ask questions for themselves. Again, what if the very thing that makes a question relevant is the person's interests informing it?

Perhaps this paper is no more than my own personal teaching statement. I know that there will be teachers who don't agree with what I am saying. Most teachers, however, will agree that our role is to make learning accessible, and in the case of foreign language teaching, to help students' learn to read, write and speak more effectively. I am confident that what I am proposing, if thoughtfully put into practice, will help accelerate learning and make it more relevant, meaningful and enjoyable.

Above all, my model forces students to become evaluative, collaborative, participatory and self-directed at an early stage in their life, when many of them are rolling along without direction. Instead of telling them where to go, let's see if we can help them find their way. 


\section{References}

Brinton, D., Snow, M. A., \& Wesche, M. B. (1989). Content-based second language instruction. Boston: Heinle \& Heinle.

Davies, P. (2006). Peer assessment: judging the quality of students' work by comments rather than marks. Innovations in Education and Teaching International, 43:1, 6982. https://doi.org/10.1080/14703290500467566

Edwards, J. G. (2013). Peer Assessment in the Classroom. The Companion to Language Assessment, A. J. Kunnan (Ed.). doi:10.1002/9781118411360.wbcla002

Felman, S. (1982). Psychoanalysis and Education: Teaching Terminable and Interminable. Yale French Studies, 63:22. Retrieved from http://www.jstor.org/stable/2929829.

Genesee, F., \& National Center for Research on Cultural Diversity and Second Language Learning. (1994). Integrating language and content: Lessons from immersion. Santa Cruz, Calif: National Center for Research on Cultural Diversity and Second Language Learning.

Krishnamurti, J. (1953). Education and the Significance of Life. New York: Harper.

Lacan, J., \& Miller, J.A. (Eds.). (1988). The Seminar of Jacques Lacan, Book I: Freud's Papers on Technique. New York: Norton.

Lightbown, P. M. \& Spada, N. (1993). How languages are learned. New York: Oxford University Press.

García Lorca, F. \& Simon, G. (1990). Poet in New York. London: Penguin Books.

Met, M. (1991). Learning language through content: Learning content through language. Foreign Language Annals, 24(4). 281-295. https://doi.org/10.1111/j.1944-9720.1991.tb00472.x

Swartz, David. (2017). A Critique of Doubt: Questioning the Questioning Method as a Means of Obtaining Knowledge. The Journal of Aesthetic Education, 51(2), 40-52. doi:10.5406/jaesteduc.51.2.0040

Whitman, W., \& Harvey, R. (Eds.). (1961). Leaves of Grass: Facsimile Edition of the 1860 Text. Pearce. Ithaca, New York: Cornell UP. 